\title{
An in Vivo Studies on the Sensitivity Pattern of Plasmodium Bergei to Stem Bark Extract of Echinaceae Angustifolia DC (Compositae)
}

\author{
Abdu Zakari ${ }^{1}$, Dimas Kubmarawa ${ }^{2}$, Sunday Osemeahon A $^{3}$, Usman Umar Modibbo ${ }^{4}$, \\ Sunday Dzarma ${ }^{5}$, Elisha Barde Baba ${ }^{6}$ \\ ${ }^{1}$ Department of Chemical Sciences, Federal University Kashere, Gombe - Nigeria \\ ${ }^{2,3 \& 4}$ Department of Chemistry Modibbo Adama University of Technology Yola - Nigeria \\ ${ }^{5 \& 6}$ Department of Pharmacology, National Institute of Pharmaceutical Research and Development Idu, \\ Abuja - Nigeria
}

\begin{abstract}
The methanol extract of E. angustifolia DC was screened for the presence of secondary metabolites and was earlier tested for the median lethal dose $L D_{50}$ using Swiss albino mice to ascertain the in vivo acute toxicity and hence the practically safe dose to be used in a three model antimalarial investigation. The result of the phytochemical screening indicated the presence of alkaloids, terpenes, tannins, flavonoids, saponins and anthraquinones. The extract was found to be very toxic to the mice, which guided our choice for practically safe dose in the three models of the antimalarial evaluations. The result of the suppressive test showed a significant $\%$ suppression compared to the control with values of $57.92 \%, 66.62 \%$, and $75.62 \%$ for the doses $100 \mathrm{mg} / \mathrm{kg}$, $150 \mathrm{mg} / \mathrm{kg}$, and $250 \mathrm{mg} / \mathrm{kg}$ respectively. The result of the prophylactic (residual malaria infection) tests showed a significant level of inhibition compared to the control for the three doses. The curative (established malaria infection) tests also showed a significant level of parasite suppression compared to the control with \% parasitemia of $0.13 \pm 0.07,0.12 \pm 0.06$, and $0.07 \pm 0.04$ for the doses 100,150 , and $250 \mathrm{mg} / \mathrm{kg}$ respectively. The result justified the use of E. angustifolia DC as remedy to malaria infection by the traditional medicine practitioners in North-Eastern Nigeria.
\end{abstract}

Keywords: In vivo Studies, Sensitivity Pattern, E. angustifolia DC, Plasmodium bergei

\section{INTRODUCTION}

The fact that resistance of human malaria parasites to anti-malarial drugs has become major concern due to the shortage of novel classes of anti-malarial drugs.

It has become necessary to prevent the resistance by using new compounds that are not based on existing synthetic antimicrobial agents [3]

Potent antiplasmodial compounds isolated from medicinal plants were reported in studies carried out both in vivo and in vitro. Compounds such as quinine, quassinoids, linonoids, and artemisinin were among antimalarial natural products isolated in the past and in recent years from plants. Some plants species today have been reported to contain antiprotozoal phytochemicals and were indicated to be potential source of drugs for many tropical diseases including malaria [6].

The spread of drug-resistant parasites was reported to be the main cause of the worsening malaria situation in recent years which also led to the rising percentage mortality associated with malaria. Efforts on the development of new drugs for malaria disease control face a great challenge of resistance of the plasmodium parasite to the old and new drugs [4]

Echinacea species were reported tohave a long history of medicinal use and were among the bestselling herbal preparations in several developed countries. Particular interest on Echinaceae spp. was in the prevention and treatment of upper respiratory tract infections. Several groups of phytoconstituents, including alkamides and caffeic acid derivatives, were found according to studies in solvent extracts of this plant spp. Evidence was found to support some of the traditional and modern uses for Echinacea spp. [3]. The in vivo acute toxicity and in vitro cytotoxicity of methanol extract of E. angustifolia DC was reported indicating its potentials use in pharmaceutical and 
toxicological studies [7]. Some clinical trials on the use of Echinacea preparations for the prevention and treatment of upper respiratory tract infections were reported to have high activity as compared to the control group [1].

\section{Methodology}

\section{A. Plant Collection and Identification}

The fresh samples of the plant was identified and collected by Clifford Emmanuel (tribe's man/research assistant) The plant was authenticated by Botanists in the Department of Biological sciences Federal University Kashere.

\section{B. Extraction}

$60 \mathrm{~g}$ of the dried and powdered sample was packed in an improvised thimble of filter paper prepared manually. The thimble was then inserted into the Soxhlet apparatus, $500 \mathrm{ml}$ methanol was transferred down the thimble into the pot. Extraction was carried out for 6 hours at a temperature of $75{ }^{\circ} \mathrm{C}$. The methanolic extract was evaporated on a rotary evaporator (R110) at $40^{\circ} \mathrm{C}$, altogether, $200 \mathrm{~g}$ of each sample were extracted and labeled F01 [7]

\section{Laboratory Animals used in the Research}

The animal models involved in this study were the Swiss albino mice acquired from the National Veterinary Research Institute (NVRI) Vom in Jos - Nigeria. The experimental procedures relating to the animals were authorized by the Ethical committee of National Institute for Pharmaceutical Research and Development (NIPRD), Abuja-Nigeria before starting the study and were conducted under the internationally accepted principles for laboratory animal use and care (EEC Directive of 1986; 86/609/EEC) [7].

\section{Volume of Extract Per Live Weight of Mice}

TheVolume of extract solution was calculated using the following expression

Volume of extract solution $=\frac{(\text { weig } h \text { t of mice } X \text { Dose })}{\text { Stock Concentration }}$

\section{E. Inoculation of the Plasmodium Parasite}

Donor Mice infected with the $P$. bergei were initially acquired from the National Veterinary Research Institute (NVRI) Vom in Jos - Nigeria and reared in the animal house of NIPRD. Blood from the donor mouse infected with the $P$. bergheiwas used for inoculum preparation. The blood from donor mouse was obtained and diluted serially in Alsever's solution. $0.2 \mathrm{~mL}$ of the final suspension which contained about $1 \times 106$ infected RBC's was injected into mice intraperitoneally to initiate infection. The inoculated animals were then randomized into five mice per group and kept in the Animal Room, Department of Pharmacology, National Institute of Pharmaceutical Research and Development (NIPRD) Idu-Abuja in accordance with the internationally accepted principles for laboratory animals' use and care.

\section{F. Suppressive Test}

The Peter's 4 days suppressive test against chloroquine sensitive Plasmodiurnberghei NK 65 infection in mice were employed. Adult Swiss albino mice were incubated by intraperitoneal (IP) injection with standard inoculums of the Plasmodium berghei with $1 \times 10^{7}$ infected erythrocytes. The mice were randomly divided into five (5) groups of six (6) mice per group and treated for 4 consecutive days with $5 \mathrm{ml}$ each of 100,150 and $250 \mathrm{mg}$ extract $\mathrm{kg}^{-1} \mathrm{~b}$. wt. orally daily respectively. Two control groups were used: Positive control were treated daily with $25 \mathrm{mg} / \mathrm{kg}$ chloroquine $\mathrm{kg}^{-1} \mathrm{~b}$. wt while the negative control were given $5 \mathrm{ml} \mathrm{kg}^{-1}$ normal saline. On day 5 of the experiment, blood was collected from the tail of each mouse and smeared on to a microscope slide to make a film. The blood films were fixed with methanol, stained with $10 \%$ Giemsa at $\mathrm{pH} 7.2$ for $10 \mathrm{~min}$ and parasitaemia determined microscopically [5]. The percentage suppression of parasitaemia were calculated for each dose level by comparing the parasitaemia in negative control with those of treated mice i.e

\footnotetext{
$\%$ suppression $=\frac{\text { mean parasitemia of negative -mean parasitemia of treated group }}{\text { mean parasitemia of negative control }} \times 100$, whereas $\%$ parasiitemia was evaluated using the following expression;
} 
An in Vivo Studies on the Sensitivity Pattern of Plasmodium Bergei to Stem Bark Extract of Echinaceae Angustifolia DC (Compositae)

$\%$ parasitemia $=\frac{\text { Number of parasitized } \mathrm{RBC}}{\text { Total number of } R B C} \times 100$

\section{G. Evaluation of Schizontocidal Activity of the Plants Extracts on Established Infection (Curative or Rane Test)}

Evaluation of the potential of the potent fractions were carried out according to modified method described by Ryley and Peters 1970. The mice were infected intraperitoneally with standard inoculums of $1 \times 10^{7}$ Plasmodium bergheiberghei NK 65 infected erythrocytes on the first day (day 0). Seventy-two hours $(72 \mathrm{~h})$ later, the mice were divided into 5 groups of six mice each. Three groups were orally treated with $100 \mathrm{mg} / \mathrm{kg}, 150 \mathrm{mg} / \mathrm{kg}$ and $250 \mathrm{mg} / \mathrm{kg}$ repectively. The remaining two groups served as negative and positive controls and administered 2\% saline solution and chloroquine 25 $\mathrm{mg} / \mathrm{kg}$, respectively [6]

The treatment was carried out once daily for 5 days and blood smears were collected and examined microscopically to monitor the parasitaemia level.

\section{H. Evaluation of the Prophylactic Activity of the Plants Extracts}

Evaluations of the prophylactic potential of extracts of the plants were carried out according to the modified method of Peters 1967. Adult mice were randomized into 5 groups of six mice each. Group 1 were given $5 \mathrm{ml}$ distilled water $\mathrm{kg}^{-1} \mathrm{~b}$. wt. orally. Groups 2, 3, and 4 were given 100, 150, and 250 $\mathrm{mg}$ extract $\mathrm{kg}^{-1}$ b. wt respectively. Group 5 were however given $25 \mathrm{mg} / \mathrm{kg}$ chloroquine (CQ) intraperitoneally. Treatments were initiated on day 0 and day 4 then, the mice were all infected with the parasite. Blood smears were then made from each mouse $72 \mathrm{hrs}$ after treatment and increase or decrease in parasitaernia were determined as described above.

\section{Statistical Analysis}

The data obtained as the mean of 5 replicates was analyzed using a univariate analysis of variance (UNIANOVA) on the SPSS package at a $95 \%$ and $99 \%$ confidence level, values of $\mathrm{P} \leq 0.05$ and $\mathrm{P} \leq$ 0.01 were considered significant, results were expressed as $\%$ of Mean \pm SD.

\section{RESUlts}

Table1. Phytochemical Constituents of Methanol Extract of Echinacea Angustifolia DC

\begin{tabular}{|l|l|}
\hline Test & Inference \\
\hline $\begin{array}{l}\text { Sapponnins } \\
\text { Terpenes }\end{array}$ & + \\
\hline Tannins & + \\
\hline Resin & + \\
\hline Phlabotannin & - \\
\hline Alkaloid & + \\
\hline Flavonoid & + \\
\hline Anthraquinone & + \\
\hline
\end{tabular}

Key: $(+)=$ present,$(-)=$ absent

Table2. Suppressive Effect of Methanol Extract of Echinaceae angustifolia DC and Chloroquine against P. bergei Infection in Swiss Albino Mice

\begin{tabular}{|l|l|l|l|}
\hline Treatment & \% Parasitemia & \% Chemo-suppression & Significance \\
\hline $10 \%$ saline (control) $(5 \mathrm{~mL} / \mathrm{kg})$ & $0.36 \pm 0.057$ & 0 & $\mathrm{NS}$ \\
\hline Extract 100mgKg-1 & $0.23 \pm 0.03$ & 57.92 & $\mathrm{P}<0.01$ \\
\hline Extract $150 \mathrm{mgKg}-1$ & $0.16 \pm 0.06$ & 66.62 & $\mathrm{P}<0.01$ \\
\hline Extract $250 \mathrm{mgKg}-1$ & $0.13 \pm 0.07$ & 75.62 & $\mathrm{P}<0.01$ \\
\hline Chloroquine (CQ) $(25 \mathrm{mg} / \mathrm{kg})$ & $0.07 \pm 0.02$ & 89.39 & $\mathrm{P}<0.01$ \\
\hline
\end{tabular}

NS = Not Significant

Table3. Curative Effect of Methanol Extract of Echinaceae angustifolia DC and Chloroquine against P. bergei Infection in Swiss Albino Mice

\begin{tabular}{|l|c|c|c|}
\hline Treatment & \% Parasitemia & \%Chemo-suppression & Sinificance \\
\hline $10 \%$ saline (control) & $0.45 \pm 0.13$ & 0 & $\mathrm{NS}$ \\
\hline Extract 100mgKg-1 & $0.13 \pm 0.07$ & 71.26 & $\mathrm{P}<0.01$ \\
\hline Extract 150mgKg-1 & $0.12 \pm 0.06$ & 74.16 & $\mathrm{P}<0.01$ \\
\hline Extract 250mgKg-1 & $0.07 \pm 0.02$ & 83.52 & $\mathrm{P}<0.01$ \\
\hline Chloroquine (25mg/kg) & $0.06 \pm 0.05$ & 86.44 & $\mathrm{P}<0.01$ \\
\hline
\end{tabular}

$N S=$ Not Significant 
Abdu Zakari et al.

Table4. Prophylactic Effect of Methanol Extract of Echinaceae angustifolia DC and Chloroquine against P. bergei Infection in Swiss Albino Mice

\begin{tabular}{|l|c|c|c|}
\hline Treatment & \% Parasitamia & \% Chemo-suppression & Significance \\
\hline $10 \%$ saline (control) & $0.23 \pm 0.02$ & 0.00 & NS \\
\hline Extract $100 \mathrm{mg} / \mathrm{Kg}$ & $0.11 \pm 0.02$ & 49.17 & $\mathrm{P}<0.01$ \\
\hline Extract $150 \mathrm{mg} / \mathrm{Kg}$ & $0.09 \pm 0.02$ & 56.56 & $\mathrm{P}<0.01$ \\
\hline Extract $250 \mathrm{mg} / \mathrm{Kg}$ & $0.07 \pm 0.01$ & 60.59 & $\mathrm{P}<0.01$ \\
\hline Chloroquine $(25 \mathrm{mg} / \mathrm{kg})$ & $0.06 \pm 0.01$ & 73.94 & $\mathrm{P}<0.01$ \\
\hline
\end{tabular}

NS = Not Significant

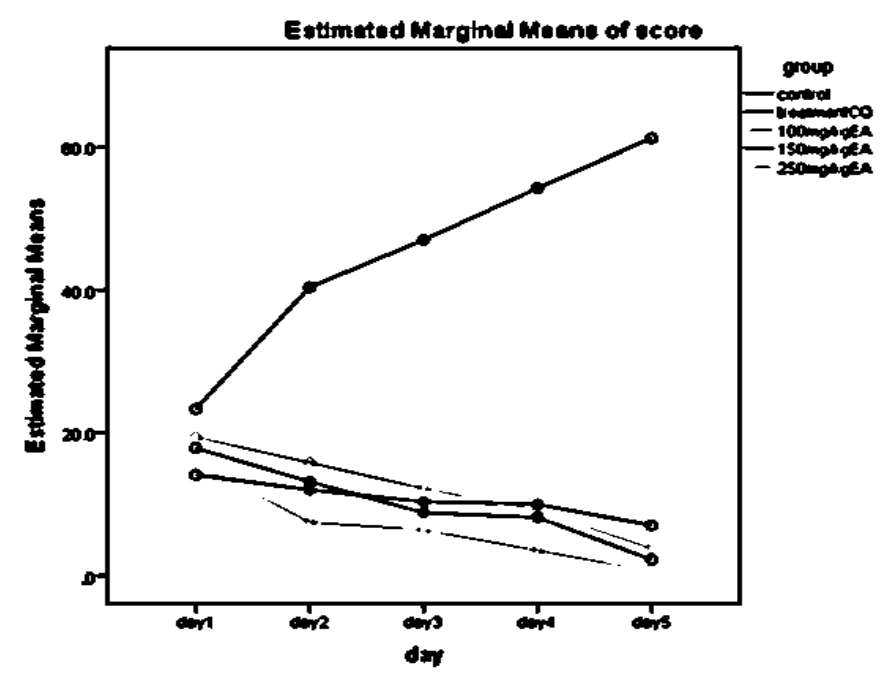

Fig1. Schizontocidal Activity of Echinacea Angustifolia DC Extract on Established Malaria Infection

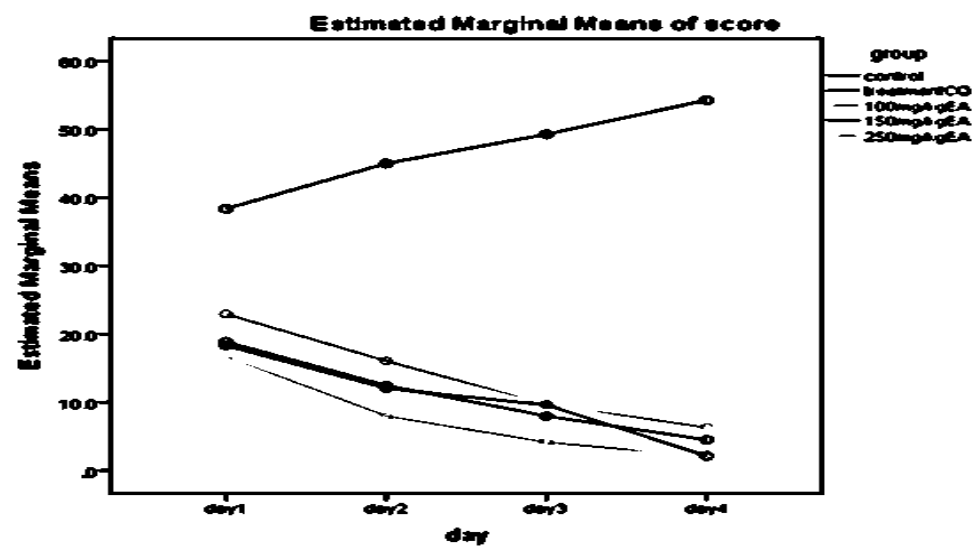

Fig2. Suppressive test result of Echinacea Angustifolia DC Extract on early Malaria Infection

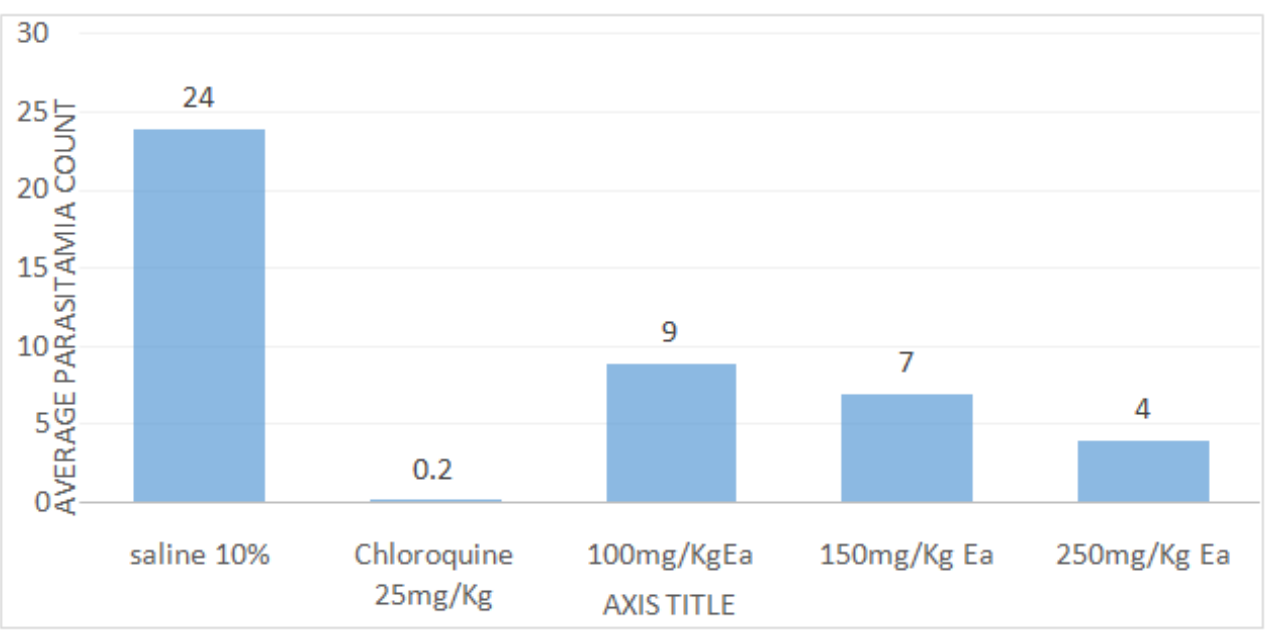

Fig3. Column Chart of Residual Malaria (Prophylactic) test result for E. angustifolia DC stem bark extract 


\section{DISCUSSION}

\section{A. Phytochemical Screening}

Phytochemical screening of the methanol extract of E. angustifolia DC stem bark revealed that the extract contained alkaloids, terpenes, anthraquinones, flavonoids, tannins, and saponins among others. Phytochemical compounds such as alkaloids were reported to exhibit antiplasmodial activity of many plants while terpenes or terpenoids have been identified as active antiprotozal and antimalarial agents in many pharmacological studies. Flavonoids revealed significant anti-parasitic activities against different parasite strains of malaria, trypanosome and leishmania. Anthraquinones derivatives showed antimalarial activity [2]. These phytochemicals found in the extract justified the use of the plant $(E$. angustifolia $D C$ ) by herbalists (traditional medicine practitioners) as a remedy for malaria disease.

\section{B. In Vivo Antimalaria Studies}

Significant in vivo oral suppression of $P$. bergheiby $E$. angustifolia $D C$ methanolextracts was investigated. Significant differences wereobserved in the mean survival of animals treatedwith the extract and untreated control. In the antiplasmodial tests, the toxicity of the plant extract guided the choice of the doses 100,150 and $250 \mathrm{mg} / \mathrm{kg}$. Significant parasite suppression was recorded in the 3 models of the antiplasmodial tests.

\section{Suppressive Anti-Malarial Activity}

The in vivo suppressive activity of three doses $(100,150$, and $250 \mathrm{mg} / \mathrm{kg}$ ) of the methanol extract of $E$. angustifolia administrated orally showed a dose-dependent chemosuppressive activity were $57.92 \%, 66.62 \%$ and $75.62 \%$ in all groups of mice (Table 2). A considerably high degree of chemosuppression was shown by the 150 and $250 \mathrm{mg} / \mathrm{kg}$ doses which significantly decreased the parasitaemia of the infected mice when compared to the negative control $(P<0.01)$.

\section{Curative Anti-Malarial Activity}

The results indicated that the methanol extract of E. angustifolia exhibited dose-dependent chemosuppression in parasitaemia. This curative chemosuppression of the treated groups was statistically significant $(P<0.01)$ when compared to the control. The control group showed increased parasitaemia on the seventh day of infection (Figure 1). The chemosuppression effects for the treated groups were $71.26 \%, 74.16 \%$ and $83.52 \%$ for 100,150 and $250 \mathrm{mg} / \mathrm{kg}$, respectively (Table 2). These treated groups $(100,150$ and $250 \mathrm{mg} / \mathrm{kg})$ of mice also had longer survival times. which ranged between 23, 25 and 27 days as compared to the control with 13 days. The chloroquine-treated group had a survival time of 29 days.

\section{E. Prophylactic Test}

The methanol extract of E. angustifolia $D C$ showed a dose-dependent prophylactic activity at the different doses employed resulting in significant $(\mathrm{P}<0.01)$ reduction of parasitaemia in extract treated groups when compared to control. Values of $49.17 \%, 56.56 \%$ and $60.59 \%$ chemosuppressions at doses of 100,150 and $250 \mathrm{mg} / \mathrm{kg}$, respectively. The chemosuppression shown by the highest dose of the extract $(250 \mathrm{mg} / \mathrm{kg}$ ) was promising when compared to that of the standard drug (Table 4).

\section{Conclusions}

The stem bark extract of $E$. angustifolia demonstrated significant $(P<0.01)$ schizonticidal activity in all the three models of the antimalarial evaluations. The results of this study besides justifying the claim of traditional medicine practitioners in the region, provides a base line data for further studies on the plant. Isolation and characterization of the bioactive principles with the ultimate objective of finding novel antimalarial compounds is in progress.

\section{ACKNOWLEDGEMENTS}

The authors wish to gratefully acknowledge the financial support of the TETFund - Nigeria. 


\section{REFERENCES}

[1] Abdu Z, Dimas K (2016) In vitro Cytotoxicity Studies and Qualitative Investigation of Phytochemicals of Stem Bark Extracts of Detarium microcarpum (Caesalpinioideae), Echinaceae angustifolia (Compositae) and Isoberlinia doka (Fabaceae).National Journal of Multidisciplinary Research and Development 1: 22-26.

[2] Abdulelah H. Al-Adhroey,, Zurainee M. Nor, Hesham M. Al-Mekhlafi, Adel A. Amran and Rohela Mahmud; Antimalarial Activity of Methanolic Leaf Extract of Piper betleL. Molecules 2011, 16, 107-118; doi:10.3390/molecules 16010107

[3] Barnes J, Anderson LA, Gibbons S, Phillipson JD (2005); Echinacea species (Echinacea angustifolia (DC.) Hell., Echinacea pallida (Nutt.) Nutt., Echinacea purpurea (L.) Moench): a review of their chemistry, pharmacology and clinical properties. J Pharm Pharmacol 57: 929954.

[4] Grace I Olasehinde, OlusolaOjurongbe, Adegboyega O Adeyeba, Obasola E Fagade, NeenaValechaIsaac O Ayanda, Adesola A Ajayiand Louis O Egwari (2014); InVitro Studies On The Sensitivity Pattern Of Plasmodium Falciparum To Anti-Malarial Drugs And Local Herbal Extracts; Malaria Journal 13:63.

[5] LaychiluhBantie, Solomon Assefa, TilahunTeklehaimanot and EphremEngidaworkBantie et al. In Vivo Antimalarial Activity of the Crude Leaf Extract and Solvent Fractions of Croton Macrostachyus Hocsht. (Euphorbiaceae) Against Plasmodium BergheiIn Mice; BMC Complementary and Alternative Medicine 2014, 14:79http://www.biomedcentral.com/1472-6882/14/79 Accessed on 03/02/2017.

[6] Renata B. S. Lima Luiz F. Rocha e Silva1,2,3, Marcia R. S. Melo4, Jaqueline S. Costa1, Neila S. Picanço1,2, Emerson S. Lima5, Marne C. Vasconcellos5, Ana Paula A. Boleti5, Jakeline M. P. Santos5, Rodrigo C. N. Amorim1, Francisco C. M. Chaves6, Julia P. Coutinho7, Wanderli P. Tadei8, AntonianaU.Krettli7 and Adrian M. Pohlit1(2015); In vitro and in vivo anti- malarial activity of plants from the Brazilian AmazonMalar J 14:508

[7] Zakari A, Kubmarawa D (2016); Acute Toxicity (LD50) Studies Using Swiss Albino Mice and Brine Shrimp Lethality (LC50 and LC90) Determination of the Ethanol Extract of Stem Bark of Echinaceae angustifolia DC. Nat Prod Chem Res 4: 240. doi: 10.4172/2329-6836.1000240 